\title{
7 \\ The body of Christ: Blasphemy as a necessary transgression?
}

\section{Carolyn D'Cruz and Glenn D'Cruz}

This chapter was originally prefaced with an audio-visual presentation showing key scenes from Martin Scorsese's film, The Last Temptation of Christ, cut to the folk hymn, 'Go Tell Everyone', which is reproduced below. The video segued into a short duologue, which dramatised the ambiguity inherent in God's call. The presentation concluded with the same hymn accompanied by images of the poor, the marginalised and the powerful.

God's spirit is in my heart

He has called me and set me apart

This is what I have to do, what I have to do

He sent me to give the good news to the poor

Tell prisoners that they are prisoners no more

Tell blind people that they can see

And set the downtrodden free

And go tell everyone, the news that the kingdom of God has come

And go tell everyone, the news that God's kingdom has come. ${ }^{1}$

Did you hear the call?

What call?

I think it's the call from God.

You think? If it is the voice of God shouldn't you know?

But it could be the voice of the devil fooling me to believe it is God. How will I ever know for certain?

You won't.

In the Last Temptation of Christ, Martin Scorsese's Jesus heard voices. He was not always sure if it was the voice of God calling him, setting him apart to redeem the world from sin, whether it was the work of the devil leading him into temptation, or whether it was just his own basic corporeal voice of desire. In any case, Scorsese's Jesus struggled between the pull of a divine plan on the one hand, and temptations of the flesh as part of living a typical life on earth on the other. In contrast to the many filmic images of Jesus that episodically rise from the dead on our television screens at Easter time - images embodied by 
the likes Max Von Sydow, Jefferey Hunter and Robert Powell - Scorsese's image of Jesus, as he puts it, does not 'glow in the dark'. Scorsese wanted to present the world with a Jesus whose human side was not effaced by his status as a deity. Adapting his filmic text from Nikos Kazantzakis's novel of the same name, Scorsese underscores the struggle that Jesus experiences as a man coming to terms with the temptations of 'ordinary' life. He experiences these temptations as strongly as the voices that call him to a duty not to himself but to others.

It is possible to read The Last Temptation of Christ as a text that responds to Scorsese's own calling. When Paramount Pictures initially agreed to proceed with the film in 1983, the studio executives asked Scorsese why he wanted to make the film; he replied: 'So I can get to know Jesus better.' ${ }^{2}$ This would come as no surprise to Scorsese scholars, as one can hardly miss the Catholic themes and iconography in films such as Mean Streets and Raging Bull. Indeed, many academic commentaries on The Last Temptation of Christ note similarities between this film and its predecessors, arguing that the entire Scorsese canon dramatises the struggle between the sacred and the profane, the body and the spirit. As Rolando Caputo notes:

Scorsese has so doggedly and publicly pursued this 'long treasured project' [The Last Temptation] that there is almost a hidden implication that he would have us believe most of his previous films were mere sketches for a canvas, of which Last Temptation is the final unveiling ... In retrospect, and not surprisingly, many of Scorsese's films are a little bit of Last Temptation, or as Kay more aptly states it, he is 'synthesising all his cinematic Scorsesisms into one film. ${ }^{3}$

Furthermore, it appears that Scorsese heard his own calling to get to know Jesus better well before he became a film director. He was brought up Catholic, served as an altar boy and wanted to become a priest before studying film at New York University. As a 'true believer', so to speak, Scorsese was attracted to Kazantzakis's novel because he found the novelist's representation of Christ accessible. While recounting an episode in his film when Christ says: 'Lucifer is inside me, he's saying I'm not the son of Mary and Joseph, I am the son of God, I am God', Scorsese says:

So he thinks it's the Devil inside him saying this, and he believes he is the worst sinner in the world. I felt that this was something I could relate to: this was a Jesus you could sit down with, have dinner or a drink with. ${ }^{4}$

If we were to give any weight at all to authorial intentionality, as so many people do, we would be more than hard pressed to accuse Scorsese of wanting to make a blasphemous film. ${ }^{5}$ As far as intentions go, Scorsese recalls a priest telling him that Kazantzakis' novel was read in Catholic seminaries in order to provoke 
debate and discussion. Scorsese states: 'this is what I hoped the film would do' ${ }^{6}$ Defending Scorsese against charges of blasphemy, Jonathan Rosenbaum remarks: 'the religious doubts about Scorsese, one should stress, are not doubts about religion, but on the contrary, doubts which could only exist within a system of religious belief' ${ }^{7}$

But regardless of Scorsese's authorial intentions, despite his careful framing of The Last Temptation as a fictional text, he was bound to offend the self-appointed guardians of Christianity over the way the story of Christ should be told. It ought to be common knowledge that as a text, The Last Temptation of Christ will be read in a variety of institutional and discursive circumstances and contexts that generate different meanings. Cinemagoers, for instance, might be interested in the film's aesthetic qualities, seminaries might use the film as a pedagogical tool, and equally some viewers might find the thought of Jesus Christ having sex on film titillating. As we will see, Christian fundamentalists used the film to galvanise their constituency against what it saw as moral corruption. So, if Scorsese was intent on provoking 'debate and discussion' on his particular religious calling, he could not escape doing so among a cacophony of other receivers of the call.

In this sense, Scorsese's struggles presented through the non-'glow in the dark' Jesus are not unlike our own. Perhaps each of you has heard a calling. Perhaps it is a religious calling and you are certain it is the voice of God. Or perhaps, in accord with the seemingly secular context of the modern academy, you might prefer to think of a calling as the voice of conscience or reason. But for some people, like us for example, even the voice of conscience and reason does not adequately capture the 'spirit' of the call to which we are responding to today. Now neither of us, the authors of this chapter, are religious in the strict sense of the term, although we have extremely divergent relationships to the heritage of Christianity. Yet the call that we underscore here and now cannot escape the messianic tone of at least one thread of Christianity's heritage: the coming of justice. Our philosophical guides for grappling with this heritage and call are located in works by Emmanuel Levinas and Jacques Derrida in particular. We will come back to these guides later. For now, let us focus on our aesthetic guide, Martin Scorsese and his fictional, cinematic re-telling of the story of Christ, which gives the hypothesis of this chapter its impetus: the contention that so-called 'blasphemy' might be a necessary transgression against the fundamentalist Christian Right, and as an important consequence, an essential ingredient for creating a more just society.

For the record, we do not believe that the film is actually blasphemous, if we take blasphemy to mean 'a contemptuous or profane act or utterance, or writing concerning God' ${ }^{8}$ Christ is tempted by flesh in the film, but he does not succumb to it. He wonders if he is merely mortal, but eventually accepts his divine calling. 
But this is beside the point. The point is that the charges of blasphemy were made by a tightly organised, relatively powerful group of Christian fundamentalists - most notably the National Federation for Decency led by Donald Wildmon in the United States - who were able to disrupt the very production of the film, years before it even made it to the screen.

In charting these attempts to censor the film, we get an idea of just how influential fundamentalism can be in determining who gets to speak about Christ, and how Christ must be spoken about in order to speak legitimately. It also shows who gets to define blasphemy.

In his book, The Man the Networks Love to Hate, Donald Wildmon recalls that when he first heard about Paramount's plans to fund Scorsese's Last Temptation, he orchestrated a nationwide campaign to prevent the film's production. He exhorted Christians to express their outrage by bombarding Paramount with letters, phone calls and postcards of protest. 'Thankfully', Wildmon states, 'this flood of communication convinced Paramount, which had already spent \$2 million on the Last Temptation project, to cancel its plans'. 9 Paramount's withdrawal from the project generated apprehension throughout the film industry, and for a short while, it seemed that the film would find no producer.

Five years later, Scorsese secured the backing of Universal, a subsidiary of the Music Corporation of America (MCA), on the proviso that he would produce, direct and develop his subsequent projects exclusively for them. The company gave The Last Temptation 'a budget less than half of the average Hollywood film'. ${ }^{10}$ Universal tried a number of methods to defuse religious controversy, and went as far as hiring conservative religious opinion makers as consultants for marketing the project (the consultants later resigned after their calls for revising two thirds of the script went unheeded). Still controversy could not be defused. This time, the fundamentalist response was even more extreme, and widespread. In fact, Christians of various denominations joined the fundamentalist protest all over the world (some even bombed a Parisian theatre). Needless to say, very few protesters had actually seen the film. Nonetheless, the scale of the protests against the movie was unprecedented. Wildmon engaged in a media blitz that saw him appear on network television shows such as Oprah and Good Morning America. He sent 250 copies of the script to what he calls 'influential' Christian leaders, and recalls that his organisation, the American Family Association (AFA),

recorded a three-minute Last Temptation-related radio spot that was soon airing on 800 Christian radio stations nationwide. We also hurried to produce a 30-minute television program attacking the movie. It aired on more than 50 Christian stations and cable networks. We urged people to protest by writing and calling MCA/Universal. Our AFA phone number 
also appeared so people could call and request a special petition asking local theatre owners, out of respect for Christians in their community, not to show the film. But this was only the beginning. In July I wrote to 170,000 Christian pastors and asked them to promote the protest effort in their churches. I also sent out more than three million letters to Christian lay people. ${ }^{11}$

Following the example set by Wildmon and his organisation (by now re-named the American Family Organisation), other fundamentalist organisations such as the Campus Crusade for Christ, under the direction of Reverend Bill Bright, 'offered followers a 'Last Temptation Battle Plan', complete with information packet and video on the life of Christ'. ${ }^{12}$

As David S. Olson notes in his recent account of the American Family Organisation's campaign against The Last Temptation of Christ, the fundamentalist protest was effective. Three Republican Congressmen attempted to pass a resolution that the film be withdrawn from circulation, and the film lost money at the box office because many cinemas refused to screen it. (It recovered a little over half of its production costs). ${ }^{13}$ Indeed, only cinemas associated with MCA would actually screen the film. ${ }^{14}$ It is still illegal to watch the film in Chile, and when the film was released on video, the Blockbuster chain refused to carry it. Controversies surrounding the film were re-ignited in the mid 1990s when it first appeared on national television in Britain and Canada. In fact, according to the Independent Television Commission, The Last Temptation held the record for the most complaints received by a television station in 2003. This record of 1554 complaints was broken only recently in June 2005, when Jerry Springer the Opera attracted more than 15,000 complaints when aired on the British Broadcasting Association. ${ }^{15}$ Clearly, when the Christian Right embarks on a campaign to censor particular representations of Christ, one thing is certain: millions of Christians throughout the world will dismiss texts that they have never seen, even though they might be spiritually and theologically engaging.

So, why did the fundamentalists protest so much? What incited one Reverend Bright to describe the film as 'absolutely the most blasphemous, degenerate, immoral, depraved script and film that I believe it is possible to conceive'? ${ }^{16}$

To begin with, it seems that representing Christ with the fascinating possibility that he too struggled with doubts, fears and passions, like other human beings, was far more shocking than the supposed 'true' flawless Christ told through the Bible's gospels. The irony is that this overtly fictional representation of Christ allows audiences to grapple with Christ's story in ways that traditional Hollywood depictions of Christ do not. As Jonathon Rosenbaum puts it: 'serious engagement with doctrine is considered blasphemy, yet Hollywood representations of Biblical incidents are viewed unproblematically, even though they are dependent on a series of almost arbitrary and often absurd representational conventions' ${ }^{17}$ 
Predictably, the fundamentalists also objected to the presence of women at the Last Supper. But more than anything else, they objected to the portrayal of Christ as having sexual impulses. He is depicted, in the infamous 'dream sequence', as making love to Mary, sister of Lazarus. Notwithstanding the fact that this sequence is presented as Christ's last temptation - the desire to produce a family and make a life with them, as so many other human beings do - the Christian Right was intent on preserving Christ's call to sacrifice himself for the sins of the world as completely unequivocal. If the presentation of a doubting Christ makes this film blasphemous, then we certainly do believe that blasphemy is a necessary transgression for redeeming some of the sins of the world today. For without having doubt about the sanctity of our calls - without pausing to ask how we might distinguish the calls of God from those of the Devil - what sort of responsibility would we be taking for our ethical behaviour?

This is not to suggest a nihilism or relativism in the making of ethical decisions. It is rather to acknowledge that ethical decisions are caught within conceptual distinctions such as Go(o)d and (D)evil, which, like all antithetical values, are not independent and complete entities in themselves, but knotted together in the very acquisition of their meaning. ${ }^{18}$ While Nietzsche exploits the exposure of the conceptual complicity between Good and Evil in his campaign against morality, thinkers like Derrida and Levinas, as we will see below, explicitly link the non-totality of conceptual opposites to the opening toward the Other. This opening toward the other is known as the ethical relation. The Other for Derrida and Levinas cannot be known in advance, so in order to be responsive to the call of the Other we must endure the passage of suspending all reliance on a programmatic, universalised morality.

The scandal over the film clearly illustrates that responding to the Christian heritage is governed not so much by who hears the call, nor even who answers, but whose voices acquire power to not only name the call, but act on its behalf. This kind of fundamentalist response to art as outlined above begs a terrifying comparison with George Bush's recent proclamation that 'God told me to invade Iraq'. For what Bush shares in common with the fundamentalist Right who frequently sabotage particular representations of Christ is both a forcing and forging of who gains propriety over the Christian heritage. Crucial differences between artists as opposed to the fundamentalists and Bush are situated in the fact that the former explicitly portray an interpretation of their own singular relationship to Christ without claiming their representations as Gospel, as it were. Both the Bush administration and the Christian Right act as if they are the 'chosen people' responding to the call of God. We are asking here today, if all of us here and now, whether Christian or not, or whether from any other religious denomination for that matter, are obliged to take responsibility for what takes place in the name of such a call. 
As mentioned earlier, if there is a call from the Christian heritage that we want to reaffirm here and now, it is a call for justice. Yet, in doing so, we are forced to reckon with all the atrocities that occur in the world today in the name of justice. Now, while we might not have the means or power to expropriate the term back from its current world stage appropriators, we do have the ability to respond to a certain spirit of justice that ties Christ's message to what Derrida, after Levinas, situates as the ethical call of the Other. For Levinas, ethics inheres in the face-to-face relation, where the self stands accused by the face of the other before its own concerns with self over-coming. It is the 'nakedness of the face' that confronts the self as a summons to responsibility in the encounter of the other's death. Levinas wrote:

The other man's death calls me into question, as if, by my possible future indifference, I had become the accomplice of the death to which the other, who cannot see it, is exposed; and as if, even before vowing myself to him, I had to answer for this death of the other, and to accompany the other in his mortal solitude. The other becomes my neighbour precisely through the way the face summons me, calls for me, begs for me, and in doing so recalls my responsibility, and calls me into question. $^{19}$

This ethical relationship to the Other is not subsumable within a universal ethics, as it is intrinsically a singular relation. Unlike Kant's categorical imperative or Mill's utilitarianism, Levinasian ethics do not have recourse to rules and maxims that guide behaviour. Like the Pharisees who Jesus castigates in the gospels (Matthew 23:23, Luke 11:42), contemporary fundamentalists promote strict adherence to the literal 'truth' of the Bible, thereby invalidating interpretations of the holy scriptures that emphasise the practice of justice over sanctimonious observance of the law.

Without detailing the intricate dialogues between Derrida and Levinas regarding how the Other gets situated in the language of ontology, ${ }^{20}$ let us focus on the fact that Derrida reinforces this singularity of the ethical relation when he distinguishes justice from law. ${ }^{21}$ For while law aims to be universal and rule-bound, answering the call for justice must attend to the singularity in which each of its calls are made. Moreover, Derrida situates law as something that is deconstructible, because it is institutional, conventional, calculable, legible and to use a famous Derridean term, 'iterable'. Justice on the other hand, is 'infinite, incalculable, rebellious to rule' and undeconstructible. For Derrida, maintaining the space between law and justice is necessary in order for the singularity of the Other to be given room to interrupt the universality and generality of calculated laws. In other words, the decision between what is just and unjust is never insured by a rule as justice comes in the form of a singular idiom. As John Caputo, $^{22}$ has noted, Jesus is exemplary here. Through the gospels that tell us 
of Jesus making the blind man see, of saving the whore from being stoned to death, and of raising Lazarus from the dead, we find the ethical resonance of the face-to-face relation, where Jesus attends to the Other's command each time he is called: singularly.

In presenting Jesus in all his human frailty (yet without discounting his divinity), Scorsese opens a space from which we can perceive ourselves struggling over the receiving end of a call. Who's calling you? The Bush alliance? The casualties of war? Or your neighbour in her everyday struggles? Do you respond to a programmatic, universal 'Ethics', or are you finding yourself increasingly attuned to countless calls from singular others who suffer? These questions are not supposed to be easily answered. As outlined in what Derrida calls the aporias of justice, our role in judging the answers to these questions cannot take place by a mere instrument that calculates. Each decision in the name of justice requires a 'fresh judgment' to be made in a 'reinstituting act of interpretation'. ${ }^{23}$ If we are serious about responding to the heritage of Christ, then this requires a unique interpretation that no 'coded rule can or ought to guarantee absolutely'. 24 Furthermore, a free decision must go through the ordeal of the undecidable, which is not merely the tension between two decisions, but the negotiation with that which is beyond calculation; an impossible decision. If Christ did not struggle between his divine calling and life on earth, there would have been no sacrifice at all, but the mere robotic motions toward a destiny that had no business with free will. Yet the passage through the undecidable does not mean that we therefore forgo the making of the decision; this would reduce action to an equally inert disposition. The final aporia of justice that Derrida outlines concerns the 'urgency that obstructs the horizon of knowledge'. ${ }^{25}$ The immediacy and urgency in which incoming calls from others are received demand that a decision must be made no matter how much time and information one has at one's disposal. We must respond and act in the here and now as Christ responded to the downtrodden then and there. Such a treatment of justice - the call for a fresh judgment, the ordeal through the undecidable and the urgency of the decision - is a far cry from the programmatic doctrine of Christian fundamentalism. If the struggles of Scorcese's Jesus give us a character that is more relatable and accessible to our own ethical problems today, then perhaps the blasphemy Scorsese is accused of is a necessary transgression for reacquainting ourselves with Jesus as an ethical activist. As an accessible character, Scorsese's Jesus also invites us to ask where our own ethical calls come from, and judge what temptations we might succumb to, and what sacrifices we might make as we attempt to heed the calls. For, without struggling with these questions and agonising over our responses to them - as Scorcese's Jesus did - we would be fleeing from a responsibility for passing on the heritage that is committed to bringing the good news, so to speak, to the oppressed.

So, just as my father sent me 


\section{Now I'm sending you out to be}

\section{The spirit throughout the world, the whole of the world}

\section{Endnotes}

1 'Go tell every one' was sung at folk masses in the UK in the early seventies. We are unable to trace the author of the song.

2 Martin Scorsese in David Thompson and Ian Christie (eds), 1990, Scorsese on Scorsese, London: Faber and Faber, p.120.

3 Rolando Caputo, 1989, 'Forbidden Christ', Cinema Papers, vol. 71, p. 7.

4 David Thompson and Ian Christie, op. cit., p. 117.

5 Debates about authorial intentionality have a long history and emerge in various forms in discourses of philosophy, aesthetics, literary theory, psychoanalysis, Marxism and poststructuralism. Our own relation to the concept of intentionality is guided by Foucault's 'What is an Author?' and Derrida's 'Signature Event Context'. Neither philosopher denies intentionality its place in contributing to a text's meaning, but both question the ability of intentionality to act as final arbiter of interpretation. Michel Foucault, 1977, 'What is an Author', in D.F. Bouchard (ed.), Language, Counter Memory, Practice: Selected Essays and Interviews by Michel Foucault, D. F. Bouchard and S. Simon (trans.), Ithaca, New York: Cornell University Press, pp. 113-38. Jacques Derrida, 1988, 'Signature, Event, Context', in G. Graff (ed.), Limited Inc, S. Weber and J. Mehlman (trans.), Evanston, Illinois: Northwestern University Press, pp. $1-23$.

6 Martin Scorsese in Thompson and Christie, op. cit., p.124.

7 Jonathan Rosenbaum, 1988, 'Raging Messiah: The Last Temptation of Christ', Sight and Sound, vol. 57, no. 4, pp. 281-82.

8 American Heritage Dictionary.

9 Donald Wildmon with Randall Nulton, 1989, The Man the Networks Love to Hate, Wilmore: Bristol Books, p. 194.

10 L. Keysen, 1992, Martin Scorsese, New York: Twayn, pp. 166-186; this quotation, p. 168.

11 Wildmon, op. cit., p. 200.

12 Majorie Heins, 1993, Sex, Sin and Blasphemy: A Guide to America's Censorship Wars, New York: New Press, p. 167.

13 David S. Olson, 2001, 'The New Religious Right Versus Media Wrongs: AFA Fights Temptation', Journal of Film and Video, vol. 53, no. 2/3, p. 6.

14 Steven C. Dubin, 1992, Arresting Images: Impolitic Art and Uncivil Actions, New York: Routledge, p. 92.

15 'Springer Protests pour in to BBC', BBC News (Online), 6 January 2005. http://news.bbc.co.uk/1/hi/entertainment/tv_and_radio/4152433.stm. (Viewed 31 October 2005.)

16 Wildmon, op. cit., p. 201.

17 Rosenbaum, op. cit., pp. 281-82.

18 Friedrich Wilhelm Nietzsche, 2003 (1886), Beyond Good and Evil: Prelude to a philosophy of the future, London: Penguin.

19 Levinas, Emannuel, 1989, 'Ethics as First Philosophy', in S. Hand (ed.), The Levinas Reader, S. Hand (trans.), Oxford and Cambridge: Blackwell., pp. 75-87; this quotation, p. 83.

${ }^{20}$ For an introduction to the dialogue, spanning near to thirty years, between Derrida and Levinas, see S. Critchley, 1992, The Ethics of Deconstruction: Derrida and Levinas, Oxford and Cambridge: Blackwell.

21 Derrida, J. 1992, 'Force of Law: The Mystical Foundation of Authority', in D. Cornell, M. Rosenfeld, D. G. Carlso (eds), Deconstruction and the Possibility of Justice, M. Quaintance (trans.), New York and London: Routledge, pp. 3-67.

22 John Caputo, 1993, Demythologizing Heidegger, Bloomington, Indianapolis: Indiana University Press, p. 205.

23 Derrida, 2002, 'Force of Law', op. cit., p. 23

24 Ibid., p. 23.

25 Ibid., p. 24. 